\title{
DARK EVENTS: COMMEMORATION AND COLLECTIVE MEMORY IN THE FORMER YUGOSLAVIA
}

\section{Introduction}

The aim of this paper is to develop a new understanding of the relative darkness of commemorative events that are linked to tragedy and suffering, and which can be described as 'dark' events. As these events display considerable heterogeneity and continue to develop dynamically within often contested social and political contexts, it is important to develop a deeper understanding of them, so that they can be managed in ways that are appropriate to their often sensitive nature (Hall and Rusher, 2004; Getz, 2009; Frew, 2012; Frost and Laing, 2013). In common with the approaches taken by other authors in the categorisation of dark tourism and leisure (Strange and Kempa, 2003; Stone, 2006; Ryan \& Kohli, 2016; Powell et al., 2018), this paper aims to develop a categorisation of the relative 'darkness' of commemorative events.

This paper contributes to the emerging field of critical events studies (Lamond \& Platt, 2016; Spracklen \& Lamond, 2016) in two key ways. Firstly, it extends the geographical and cultural scope of the critical study of events in society to the countries of the former Yugoslavia, where commemorative events play a significant role in the political and cultural lives of young states with contested national narratives. Mair \& Whiftford (2013) have shown the need for scholarship in events to examine the relationship between events and their socio-cultural impacts, as well as the relationship between events and public policy agendas. Secondly, it builds on the critical scholarship of 'darkness' in other fields (Spracklen 2013, Stone, 2013) which has roots in the exploration of entertainment and leisure (Ashworth \& Issac 2015). This 
research shows how approaching 'darkness' from the perspective of events scholarship can draw our attention to the contemporary political and cultural significance of events that are linked to collective memories of 'darkness' of a kind not accessible through the leisure practices of tourists.

To analyse commemorative events associated with tragedy and suffering, this paper draws on the field of research into memory, both individual and collective, that is sometimes referred to as 'memory studies' and which has seen significant growth in recent decades (Colmeiro, 2011; Rekść, 2016; de Saint Laurent, 2017). This phenomenon has been described as the 'memory boom' (Lorenz 2010). Various theories have been put forward for this growth including; the lessening significance of the nation-state as the main bearer of collective identities, the end of a generalised faith in the optimistic direction of progress, the rise of multiculturalism and a fragmenting of identities associated with postmodernism (Olick, 2007a, 2007b). Taken together, all of these factors have been linked by researchers to a growth in interest in the importance of memory for individual and collective identity. This paper makes use of the concept of collective memory to understand the relationship between commemorative events and memory in post-conflict societies specifically, and also, more broadly, how collective memory can be used as a prism through which to view the 'darkness' of events. To do this, the paper analyses a purposive sample of commemorative events linked to Twentieth-century conflicts in the countries of the former Yugoslavia.

Concepts associated with collective memory have been applied in the events studies literature, in particular when associated with events that form part of a social background of conflict or 'dissonant heritage' (Tunbridge \& Ashworth, 1996; Frost et al., 2009; Lemelin et al., 2013). 
For example, Gapps (2009) looks at memory and authenticity through the analysis of participation in military re-enactment events, finding that events offer specific possibilities for the performance of memory, including the representation of historical memory within a social or contemporary memory context. Hall et al. (2010) and Slade (2003) describe the ANZAC day celebrations at Gallipoli as commemoration events by linking them to memory in social and collective forms. Slade (2003) in particular, examines the role that commemorative events and the travel to them have on collective representations of nationhood and identity, arguing that attendees who visit from Australia and New Zealand consume these events in a qualitatively different way from other attendees, for whom the site does not perform the same social function. David (2012) considers the role of cultural events in preserving collective memory within diasporic Sri Lankan communities, concluding that these events played a specific role in helping to preserve collective memory and identities for diasporic communities in particular. Sol et al. (2017) also look at the link between community identity and collective memory, analysing how a new event in Portugal was sanctioned by the authorities because its content related to a specific version of local collective memory which was seen as reinforcing dominant local narratives. Liao (2016) however, shows how the staging of cultural performances with certain symbolic associations subverted national narratives by invoking collective memory in Taiwan, indicating that the creation and transmission of memories through events is not a straightforward or uncontested process. In a similar manner to this paper, McQuaid (2017) examines the part that commemorative marches and parades play in post-Conflict Northern Ireland, by analysing them in the context of the collective memories of the communities involved and the relationship that the contestation of memory through events can have to society. Boukas et al. (2013) analyse the relationship between collective memory, heritage and the legacy of the Athens Olympics, showing that hosting mega-events can impact on the collective memory of a city through their contribution to place-based narratives and the 
symbolic importance of their associated infrastructure and venues. Skillen \& Osborne (2015) also focus on sports events, through an analysis of the heritage and sports cultures in terms of memory, collective identity and history and through an examination of the role of oral history in memory-making and reflection for participants in sporting cultures. Spracklen \& Lamond (2016) review the place of memory as a concept within events studies more generally, showing that it has frequently been linked to the commodification of events experiences through the creation of 'shared memories' of an event, as part of an increasingly valorised experience economy.

For this paper, memory studies is viewed through its relationship with the 'dark past' which has been recently studied in the context of dark tourism (Foley and Lennon, 1996; Lennon and Foley, 2000; Stone, Stone \& Sharpley 2008; Powell et al., 2018) and dark leisure (Spracklen, 2013); in practice there are clearly many links between these fields of study and their concepts (Biran \& Poria, 2012; Stone \& Sharpley, 2013). Although, not all dark tourism conceptualisations include death (Biran and Poria 2012) and dark tourism is not the only perspective from which to understand tourism at places associated with death (Light 2017). However, when dark tourism is described regarding its negative deviance from the norms of tourist behaviour, it is practically identical to the concept of dark leisure 'with notions of deviance, morality, and boundaries of the taboo' (Stone \& Sharpley, 2013; Yan et al., 2016; Light, 2017: 281). Despite the uncomfortable associations of leisure and tourism with suffering and death, both terms are relevant to the commemorative practices of the post-conflict Yugoslav states. The following section sets the context for the application of collective memory as a concept in this paper, by defining and exploring the term 'commemorative events'. 


\section{Commemorative Events}

Getz (2008) describes commemorative events as one kind of cultural celebration, which is related to similar types or subsets of cultural celebrations such as festivals, carnivals and religious events. Additionally, Getz and Page (2016: 108) point out that limited research attention has been given to commemorative events, despite the fact that while 'the wars might or might not be planned... victory celebrations and remembrance commemorations certainly are'. The majority of academic research to date in the field of commemorative events has been carried out on 'dark exhibitions' which involve viewing the material evidence of dark subject matter, usually in galleries and museums (Frost \& Laing, 2013).

Wars and other contested periods in a country's history play an important role in the nation's identity (Nanda, 2004) and the commemoration of these reflects on the "values and goals of nation' (Hogan, 2009: 205). From this perspective, commemorative events have a role to play as a reminder for future generations through the inclusion of anti-war messages and our understanding of these benefits from a systematic classification of their types. Commemorative events are often designed to remember historic tragic events and are organized physically close to the memorial sites (Rojek, 1993). Frew (2012) examines the sensitivities involved in the management and interpretation of 'dark' sites which are incorporated into heritage, tourism and leisure products and draws attention to the key role played by professional staff in ensuring that commemorative events are organized with sufficient care to ensure the respect of victims, their relatives and friends (Frew 2012). Frost \& Laing (2013: 1) explain that dark commemorative events are mostly held on the anniversary dates of the incidents 'to specifically remember and reflect the society upon the past occurrences and their relationship to today'. 
The same authors have developed a typology of dark commemorative events with seven basic categories to assist with understanding them in more depth - see Table 1. This typology is applied later in this paper to explain the different types of commemorative events that take place in the former Yugoslavia.

Table 1: Typology of dark commemorative events

\begin{tabular}{|c|c|}
\hline Type & Example of event \\
\hline Dark exhibitions & $\begin{array}{l}50^{\text {th }} \text { anniversary of the Enola } \\
\text { Gay dropping the atom bomb } \\
\text { on Japan }\end{array}$ \\
\hline Dark re-enactments & $\begin{array}{l}\text { Annual re-enactment of the } \\
\text { Battle of Little Bighorn, USA }\end{array}$ \\
\hline $\begin{array}{l}\text { National days of mourning or } \\
\text { remembrance }\end{array}$ & Hiroshima Day, Japan \\
\hline $\begin{array}{l}\text { Memorial services, opening of } \\
\text { memorials, concerts, } \\
\text { performances }\end{array}$ & $\begin{array}{l}\text { Anzac day at Gallipoli, } \\
\text { Turkey }\end{array}$ \\
\hline $\begin{array}{l}\text { Significant anniversaries (e.g. } \\
\text { centenaries) }\end{array}$ & $\begin{array}{l}\text { Bicentenary of the French } \\
\text { Revolution }\end{array}$ \\
\hline Parades, marches, processions & $\begin{array}{l}\text { Bloody Sunday March, } \\
\text { Northern Ireland }\end{array}$ \\
\hline Festivals & $\begin{array}{l}\text { Mt Kembla Mining Heritage } \\
\text { Festival, Australia }\end{array}$ \\
\hline
\end{tabular}

Source: Laing \& Frost (2013) 
Authors including Foley \& Lennon (1997), Slade (2003), Dunkley et al. (2011) and Winter (2011) argue that visitation of war-affected sites and related commemorations help to preserve collective memory. These themes of war and conflict dominate the dark tourism literature, (for example Šuligoj, 2016a; Light, 2017). Thus, dark tourism is frequently seen as primarily the visitation of sites and events that are linked to with disaster, suffering, violence or death (Stone, 2005: Stone \& Sharpley 2008), but which can also be associated with remembrance, education or entertainment as well as with political manipulation or economic development (Ashworth \& Hartmann, 2005; Stone, 2006; Stone \& Sharpley, 2008). However, Podoshen and Hunt (2011), taking the example of the Jewish community, found that they, affected by a variety of factors (including political), avoid visitations of physical locations that uniquely commemorate the Holocaust in Germany and Poland, indicating that, this is no longer an 'obligation' for them; this assumption had previously been indicated in the first studies in of this visitation in the 1990s, e. g. Dann (1994). This means that visitors' motivations are not necessarily always directly related to simulation, interaction or/and integration of themselves with death and suffering, although some groups can behave in more expected ways (Podoshen, 2013). Consequently, we can conclude that visitation of 'dark sites' and commemorative events is not necessarily always best understood from the perspective of tourist activity alone, as was also found to be the case for young residents of Croatia, who displayed more complex motivations (Šuligoj, 2016a).

From the perspective of the portfolio of events (Getz, 2005; Getz \& Page, 2016) within a destination, the top-level of the pyramid is occupied by events that we can identify as megaevents with high tourism potential. In contrast, regional and local events occupying the base level of the event portfolio are not necessarily connected to tourism, or they might even in some cases be threatened by it. The organisation of local events with primarily community, cultural 
or commemorative orientations is in many cases carried out only with the intention of benefitting residents, and therefore may actively seek not to involve outsiders, including tourists. This holds even truer for many commemorative events of the kind discussed in this paper, as they are often highly significant occasions for local communities and might not be understood by tourists. This should be consdiered using the definition that 'tourism is defined as the activities of persons travelling to and staying in places outside their usual environment for not more than one consecutive year for leisure, business and other purposes not related to the exercise of an activity remunerated from within the place visited' (Commission of the European Communities, Eurostat \& Organisation for Economic Co-operation and Development \& World Tourism Organization \& United Nations Statistics Division, 2001: 1). In fact, when at least one overnight stay in fact is not included in many commemorative events, then we find that these events are not necessarily tourist events or part of a dark tourism offer in a destination and it is therefore also necessary to consider these events on their own terms, from the perspective of the field of critical events management research.

Despite this ambiguous connection to the practices of dark tourism, it is important to consider the place of commemorative events within more broad patterns of leisure and consumption. The forms and practices of commemorative events change as society evolves (Frew \& White, 2015). Because of this dynamism, these events are presented in different types and sizes, attracting not only the families and relatives to honour those who have died but, in the context of contemporary events, also for socialization reasons connected to culture, sport, recreation and leisure. The biggest challenge for the organizers of contemporary commemorative events is to incorporate content related to the tragedy that is being commemorated, along with new forms and types of event activity which engage the attendees in a thoughtful and positive way (Laing \& Frost, 2013) through the 'history, memory and practices of commemoration' (Sather- 
Wagstaff, 2011: 193). Lennon and Foley (2000: 147) comment that 'the commercialization of traumatic heritage has erased the line between the political-educational significance and tourism consumption'.

Today, especially in the former Yugoslavia region, more and more commemorative events are organized. Some of these events are anniversaries from more than one hundred years ago, and outside the scope of living memory, but still others draw on the fresh memory of recent wars and tragedies, which are the focus of this paper, for example, the mass killings in Srebrenica 1995, and The Vukovar massacre in 1991. Maintaining the public awareness of historical facts and managing the ethical issues involved when organizing commemorative events, so as not to over-commercialize and trivialize the past, has always been a key issue for commemorative events organizers. Similar ethical issues have been discussed since the 1990s in the dark tourism literature (Seaton, 1996, 1999; Lennon \& Foley, 2000; Potts, 2012). Consequently, despite a lack of consensus about the definition of deviant or dark leisure, the integration of; negative or perceived immoral activity (Stebbins et al., 2006), e.g. involving death, sex, gambling, consumption of psychoactive substances or violence, which are promoted for casual consumption (Bryant, 2011; Smith, 2014), and memorial practices (including dark tourism) based on the victims of violence/conflict, are linked to the concept. Such practices can be understood, if we use Williams' (2009) defintion, as bad, pathological, dangerous or even criminal, although Stone and Sharpley (2013) see involvement in many of these activities as only part of the the ongoing processes of the renegotiation of moral boundaries and ethical principles in a contemporary society marked by the proliferation of taboos. 
Beside morality and deviance, a number of other elements impact on the experience and understanding of 'dark' sites (Yankholmes \& McKercher, 2015), meaning that it is common to find these sites categorized using a 'spectrum of supply' (Stone, 2006). Stone ranked 'dark products' from 'darkest' through to 'lightest' (a total of 6 degrees), also taking into account their educational, commercial, spatial, political and ideological aspects. Ryan \& Kohli (2016) also argue that temporal, political and ideological factors all have influence on visitor perceptions of the 'darkness' of attractions. Stone's (2006) ranking is in line with ranking of the authenticity of dark locations constructed by Miles (2002), who proposed a distinction between 'dark', 'darker' and 'darkest' tourism, which later Strange and Kempa (2003) extended by proposing more 'shades' of this type of tourism. Recently, this approach of considering dark tourism products on a spectrum of darkness has been further developed by Powell et al. (2018) who extended a similar categorisation to European cities, to create a ranking of urban tourism destinations by 'darkness' The authenticity or otherwise of the location of a dark tourism attraction or destination is a core element at the darkest end of Stone's (2006) spectrum, but the amount of time that has elapsed since the original event which inspired the attraction is also an important factor. Thus, those attractions related to more recent tragedy and suffering are classified as 'darker' from the perspective of contemporary visitors. Those attractions which are both linked to recent memory and sited in an authentic location are regarded as the darkest in this approach. The following section of this paper will introduce the concept of collective memory as an approach for understanding the role that memory plays in the 'darkness' of commemorative events linked to tragedy and suffering.

\section{Collective Memory}


Collective memory is a concept that has been discussed across a variety of scholarly fields for more than one hundred years, but for which there is no acknowledged categorical definition (Kansteiner, 2002). Its precise ontological status is controversial (Garagazov, 2016). There is widespread acknowledgement in the social psychology and cognitive psychology literature that there is a social component to memory, although the mechanisms for this are disputed (McQuaid, 2017). Researchers who take an individualist approach to psychology emphasise the 'collected' memories that build up over an individual's lifetime, whilst collectivists privilege the role of communities and groups in providing a framework and set of stimuli that help individuals to remember (Breitwig, 2014). Collective memory is stored externally, in books, stories, maps and ceremonies, and exerts an influence on individual memories through formal and informal social mechanisms including rumour, commemorative events, media narratives and political pronouncements (Podoshen \& Hunt, 2009; Breitwig, 2014; Barash, 2016; Dan, 2017).

The origin of collective memory studies in the social sciences is most often traced to Halbwachs $(1925 / 1992)$, who considered the workings of the individual mind to only make sense when considered alongside the presence of other minds. The social arrangements that govern relationships with the other being a strong determinant of all individual thought processes, including memory: 'It is in society that people normally acquire their memories. It is also in society that they recall, recognize, and localize their memories' (Halbwachs, 1992: 38). Collective memory is one of the four forms of memory identified by Halbwachs, along with 'autobiographical memory' which is related to events we have ourselves experienced, 'historical memory' which is contained in historical records, 'history', defined as the past to which we feel no connection and 'collective memory, being an active past which forms our contemporary identities. Garagazov defines this approach to collective memory as 'a widely 
shared knowledge of past social events that are collectively constructed through communicative social interactions, which can have significant impact on our behaviour, feelings, and thoughts' (2016: 28).

Viewing collective memory from the perspective of the social interactions that form and transmit it, draws our attention towards two considerations of relevance to this paper, which seeks to understand the relationship between collective memory and commemorative events. Firstly, how specific places and historical events are selected and constructed for commemorative events and secondly, whether the use of an event for commemoration has a specific role to play in collective memory. Pierre Nora has considered the functional ways in which collective memory can be situated and processed. According to Nora (1989), there has been a collapse of traditional forms of the transmission of memory such as local festivals, storytelling, and the close residential proximity of family members in adulthood, and at the same time a lessening of the influence of the conservative ideologies of family, church and state. In the face of the postmodern growth of the mass media and communication technologies, collective memory is increasingly based on specific sites and symbolic constructions, which have gained increased symbolic power as the traditional structures of collective memory have weakened. Nora calls these new phenomena 'Lieux de memoire' which 'originate with the sense that there is no spontaneous memory, that we must deliberately create archives, maintain anniversaries, organize celebrations, pronounce eulogies, and notarize bills because such activities no longer occur naturally' (1989: 12). These sites of memory can be identified in museums, books, commemorative events, and in documentary reporting (Colmeiro, 2011), places 'where memory crystallizes and secretes itself' (Nora, 1989: 7). 
This understanding of the social role of collective memory has been termed the 'pragmatic' perspective on collective memory, which critiques the reasons why certain memories become or remain active in a collective sense, and examines the role that these memories play in shaping the present (Bartlett, 1995; de Saint Laurent, 2017). Although organic expressions of collective memory are common, commemorative events that are linked explicitly to attempts to manipulate or represent collective memories are part of a network of power and control involving what Kansteiner (2002) described as 'memory makers' and 'memory consumers'. This approach designates those with the power and influence to shape collective memory as producers and those individuals and groups that are the object of this process as consumers. Milošević (2017) describes the different participants in this process as 'memory actors' with varying degrees of influence. Podoshen \& Hunt (2009: 313), in their analysis of the relationship between collective memory and consumption, analyse the role that speakers at events can play in imposing specific versions of memories, 'real or otherwise', through their prominent role at commemorative events. Especially when considering national collective memory, or the collective memories of large groups, it must however also be recognised that despite the presence of dominant narratives, or top-down attempts to control versions of collective memory and thus identity, that counter-perspectives and resistance always exist (Gugushvilli \& Kabachnik, 2017). Anderson (2006) asserts that all communities, from the very small to the nation state, are 'imagined' and this paper builds on this strand of research into identity and community to look at the role of commemorative events in these imaginative processes.

Memory and collective memory studies have taken a significant interest in the countries of the former state of Yugoslavia, mostly because of the long history of conflict in the Balkans and 
the active role that this history plays in contemporary politics in the region (Karge, 2009; Ramet, 2013; Putnik, 2016; Akrivoulis, 2017; Maksimović, 2017). The following section of this paper sets out this regional context, within which the contemporary role of events in collective memory will then be examined.

\section{Overview of twentieth century conflicts in the Former Yugoslavia}

The Balkan Peninsula has been one of the main focal points of global conflict in Europe. At the beginning of the twentieth century, and just before the First World War (WWI), there were the First and the Second Balkan Wars. The main consequence of the first was the end of the Ottoman domination and the liberation of some South Slavic nations, Albanians and Greeks, while the second war began a period of fresh conflict among new countries in the region meaning that the Ottomans and Romanians were involved as well (Hall, 2000; Lampe, 2014). Before the consequences of these wars were dealt with in the region, Archduke Franz Ferdinand of Austria and his wife were assassinated by Serbian activist Gavrilo Princip in Sarajevo, on $28^{\text {th }}$ June 1914 . This action is seen by many as the catalyst that began WWI, one of the bloodiest conflicts in human history. Two military fronts then opened in the territory of the former Yugoslavia: the Balkan front in 1914, and the Isonzo front as part of the Italian battleground in 1915. There was further conflict on the Adriatic Sea, where Pula, as the main Austro-Hungarian Military port, was bombarded several times, and some ships were sunk in the Central and North Adriatic (Marsetič, 2013; Perović, 2006). Consequently, many military cemeteries and charnel houses on these former battlegrounds stand as evidence to the numbers of victims and their national heterogeneity, as well as to contemporary attitudes towards the victims of war. 
After WWI, the provisional State of Slovenes, Croats and Serbs was renamed to the Kingdom of Serbs, Croats and Slovenes, and then in 1929 renamed again as the Kingdom of Yugoslavia (Bevc, 2009; Gulić, 2014; Luthar, 2008). The western parts of the territories of the Slovenes and Croats at this point was the annexed to the Kingdom of Italy, where residents were subjected to a brutal fascist repression (Bartolini, 2008; Dukovski, 1998, 2008; Pirjevec, 1982, 2016). A strong and organised anti-Slavic orientation developed in the Italian state, which included the complete prohibition of the public use of Slavic languages or the enactment any Slavic cultural traditions, along with state torture and murder (Pirjevec, 1982, 2001).

Resistance to Italian rule escalated during the Second World War (WWII), when, after the capitulation of Italy, Nazi Germany took over this territory. The culmination of violence against local rebels and anti-fascists was the opening of a temporary Nazi prison (La Risiera di San Sabba/Stalag 339/Rižarna) in September 1943 in Trieste (La Storia, 2017), while in the independent state of Croatia, the Ustasha regime established a network of concentration camps, of which Jasenovac has been become the best known (Spomen područje Jasenovac, 2017). A similar network of concentration camps was established by Nazis or other Axis forces in other parts of occupied Yugoslavia (Ferree, 2017). In addition, many battles of the national liberation struggles of this period, and the role of the partisan movement of Josip Broz Tito are well known in Yugoslav historiography. These were further promoted with recorded partisan films that attained cult status within the post-WWII Yugoslavia (Zvijer, 2014). After WWII, Yugoslav historiography and the national film industry systematically concealed all the revanchist post-war killings, which many researchers today now clearly describe as part of the communist revolution (Možina, 2016; Marijan, 2016; Dežman, 2014; Ferenc, 2013; Hribar, 1988). These topics became part of public and expert debate only after the collapse of the Yugoslavian Federation in the 1990s. In Slovenia, which was the least burdened with the 
Balkan conflicts, they were the first to excavate the remains of people killed in the post-war period (Ferenc, 2012, 2013) and the first religious and commemorative events related to this period were also introduced in Slovenia. Since then, the general public in the region has frequently been confronted with new narratives, which have affected their knowledge of recent history. However, only a few of such sites have become attractive to visitors, as this topic has been highly politicized and sharply divides societies in the post-Yugoslav countries.

In the 1990s, post-Yugoslav countries were involved in the largest military conflict in Europe since WWII (Hasic, 2004; Šuligoj 2016a) when Croatia, Bosnia and Herzegovina and Kosovo were engaged in conflict with Serbia and Montenegro. The re-emergence of concentration camps and mass graves are just some of the indicators of the ethnic cleansing which took place on a range of sides during these conflicts, with many sites of genocide as defined by United Nations (1951), such as in Srebrenica or Kozarac. Post-Yugoslav countries, after the proclamations of independence in the 1990s and the eventual resolution of conflict through the Dayton Accords (U.S Department of State, 1995), democratized and, after international recognition, became members of international institutions. Slovenia, as the most developed of the former Yugoslav republics, has been the most successful in this sense, followed by Croatia, while the other countries continue to experience ongoing developmental issues. These countries have not yet developed strong institutions or civil society and their identities remain subject to internal disagreements and border issues. Along with the resurgence of memories of the past, especially seen in the popularity of radical parties and associations, this makes regional cooperation and reconciliation more difficult, and sets the context within which a proliferation of commemorative events takes place within the countries of the former Yugoslavia. The next section of this paper explains the methods that were used in this research, to analyse the contemporary role of these events. 


\section{Methods}

This research took an interpretive (Lincoln, 1995; Veal, 2007; Saunders et al., 2009) approach to developing an exploratory, cross-case study analysis (Stake, 2008; Yin 2014) of a purposive sample (Lavrakas, 2008) of commemorative events associated with conflicts in the countries of the former Yugoslavia. The research used a case study approach because, as Creswell (2007: 74) explains, a case study approach is appropriate when the 'inquirer has clearly identifiable cases with boundaries and seeks to provide an in-depth understanding of the cases or comparison of several cases'. Yin (2003:1) also suggests that a case study methodology is the most appropriate for exploratory research such as contained in this paper, and when the focus is 'a contemporary phenomenon within some real-life context.' Case study research is frequently employed in the broad areas of social science and management research (Fljyberg, 2006; Myers, 2013) and is well established as an approach in the events management literature (Fox et al., 2014; Draper et al., 2018). The cases used in this analysis were based on data from five years of fieldwork, which included interviews, direct observations and museums/memorial centres visits. This fieldwork has informed a number of previous publications (Šuligoj, 2016a, 2016b, 2017a, 2017b), but has not previously been used to examine commemorative events, specifically.

To analyse the relationship between collective memory in the countries of the former Yugoslavia and commemorative events, a two stage purposive sampling process (Kemper et al., 2003; Lavrakas, 2008) was followed. Through this process, commemorative events for the analysis contained in this paper were selected, which was informed by the fieldwork process and following a review of the published literature in this area. The sample was selected using 
the following criteria. Firstly, the events must be contemporary commemorations, not historical events. Secondly, the events must be judged by local expert stakeholders to have significant impacts on collective identities. The final criteria was that the events must be linked to twentieth century conflicts, so as to provide a more manageable sample and to exclude events linked to ancient or mythical events, which although they may exert an influence on the collective memory, fall outside the scope of this study. The first stage of this sampling process generated a sample of 32 commemorative events across the countries of the former Yugoslavia and one event in each of Italy and Austria, in territory with historical links to the contemporary states included in this research. Each of these events was classified using Frost and Laing's (2013) classification framework, which was explained above.

From this sample of 32 events a smaller, extreme case sample was drawn to identify a set of case studies (Yin, 2014) that could be used to illustrate the nature of the events under consideration in this paper. The extreme case sampling method was chosen to develop a more clear focus for this analysis on the theme of this paper (Patton, 2005; Onwugbuzie \& Leech, 2007), which meant that events were selected for inclusion where the links to contemporary political and cultural contexts were most clear and also with the aim of developing a sample with a broad spatial coverage of the countries of the former Yugoslavia. These commemorative events form the basis of the analysis and discussion section, below, and are numbered as corresponds to their place in the more broad sample used for the first phase of this research, and also indicated by letters in table 2. Their locations are shown in figure 1. Official figures for attendance at these events are problematic for a number of reasons. The contested nature of many of these events means that attendance figures are often manipulated to exaggerate or understate the significance of the occasion. Frequently, different media outlets and event stakeholders will report very different figures. Where the event takes place in 
disputed territory, different versions of the same event may take place, and various groups may boycott them in various years for political or other reasons. Because of this, the authors have created estimates of the total number of attendees from a number of sources, to give an indication of the nature of the events included in the sample.

Table 2 - Sample of commemorative events in the Former Yugoslavia

\begin{tabular}{|c|c|c|c|c|c|}
\hline Sample & State / Event & Type $^{\mathrm{i}}$ & $\begin{array}{l}\text { Micro } \\
\text { location }\end{array}$ & Background & $\begin{array}{l}\text { Estimated Number of } \\
\text { attendees }\end{array}$ \\
\hline \multicolumn{6}{|l|}{ Slovenia } \\
\hline $3(\mathrm{~A})$ & $\begin{array}{l}\text { Memorial events } \\
\text { associated with } \\
\text { the Isonzo front }\end{array}$ & SA & Kobarid & $\begin{array}{l}\text { WWI: Isonzo } \\
\text { front (1915-1917) } \\
\text { along the current } \\
\text { Italian-Slovenian } \\
\text { border }\end{array}$ & c. $1,000-2,000$ \\
\hline \multicolumn{6}{|l|}{ Croatia } \\
\hline $6(\mathrm{~B})$ & $\begin{array}{l}\text { Day of } \\
\text { Remembrance for } \\
\text { the victims of } \\
\text { Vukovar }\end{array}$ & $\begin{array}{l}\text { NDR, } \\
\text { PMP }\end{array}$ & Vukovar & $\begin{array}{l}\text { Homeland war in } \\
1990 \mathrm{~s}\end{array}$ & c. 64,000 \\
\hline $7(\mathrm{C})$ & $\begin{array}{l}\text { Celebrations of } \\
\text { the Victory and } \\
\text { Homeland } \\
\text { Thanksgiving } \\
\text { Day and the } \\
\text { Croatian Veterans } \\
\text { Day }\end{array}$ & $\begin{array}{l}\text { NDR, } \\
\text { PMP }\end{array}$ & Knin & $\begin{array}{l}\text { Homeland war in } \\
1990 \mathrm{~s}\end{array}$ & c. 8,000 \\
\hline \multicolumn{6}{|c|}{ Bosnia \& Herzegovina } \\
\hline
\end{tabular}




\begin{tabular}{|c|c|c|c|c|c|}
\hline 12 (D) & $\begin{array}{l}\text { Srebrenica } \\
\text { Memorial Day }\end{array}$ & $\begin{array}{l}\text { NDR, } \\
\text { MSP }\end{array}$ & Potočari & $\begin{array}{l}\text { Mass killings in } \\
\text { Srebrenica and its } \\
\text { surroundings in } \\
\text { July } 1995\end{array}$ & $\begin{array}{l}\text { c. } 20,000-50,000 \text { (this has } \\
\text { varied enormously due to } \\
\text { the timing of significant } \\
\text { anniversaries) }\end{array}$ \\
\hline $14(\mathrm{E})$ & $\begin{array}{l}\text { Commemoration } \\
\text { of Jasenovac } \\
\text { victims }\end{array}$ & MSP & $\begin{array}{l}\text { Donja } \\
\text { Gradina }\end{array}$ & $\begin{array}{l}\text { WWII: } \\
\text { commemoration } \\
\text { of the Serb } \\
\text { victims of the } \\
\text { camp }\end{array}$ & c. 2,000 \\
\hline $16(\mathrm{~F})$ & $\begin{array}{l}\text { The anniversary } \\
\text { of the } \\
\text { assassination in } \\
\text { Sarajevo }\end{array}$ & SA & Sarajevo & $\begin{array}{l}\text { WWI: The } \\
\text { assassination of } \\
\text { Archduke Franz } \\
\text { Ferdinand of } \\
\text { Austria }\end{array}$ & c. 30,000 \\
\hline \multicolumn{6}{|l|}{ Serbia } \\
\hline $23(\mathrm{G})$ & $\begin{array}{l}\text { Anniversary of } \\
\text { the military - } \\
\text { police action } \\
\text { "Oluja," (Storm) }\end{array}$ & MSP & Novi Sad & $\begin{array}{l}\text { Balkan conflict in } \\
\text { 1990s: } \\
\text { Commemoration } \\
\text { of Serbian } \\
\text { victims in Croatia }\end{array}$ & c. 30,000 \\
\hline $\begin{array}{l}24 \\
\text { (H) }\end{array}$ & $\begin{array}{l}\text { Anniversary of } \\
\text { NATO bombing }\end{array}$ & MSP & Grdelica & $\begin{array}{l}\text { Balkan conflict in } \\
1990 \mathrm{~s}\end{array}$ & $\mathrm{C}, 2,000-5,000$ \\
\hline \multicolumn{6}{|c|}{ Montenegro } \\
\hline (I) & $\begin{array}{l}\text { Ceremonies of the } \\
\text { Day of Victory }\end{array}$ & NDR & Podgorica & End of WWII & c. 2,000 \\
\hline
\end{tabular}




\begin{tabular}{|l|l|l|l|l|l|}
\hline & $\begin{array}{l}\text { over fascism in } \\
\text { World War II }\end{array}$ & & & \\
\hline
\end{tabular}

Figure 1 -Location of sampled commemorative events in the former Yugoslavia

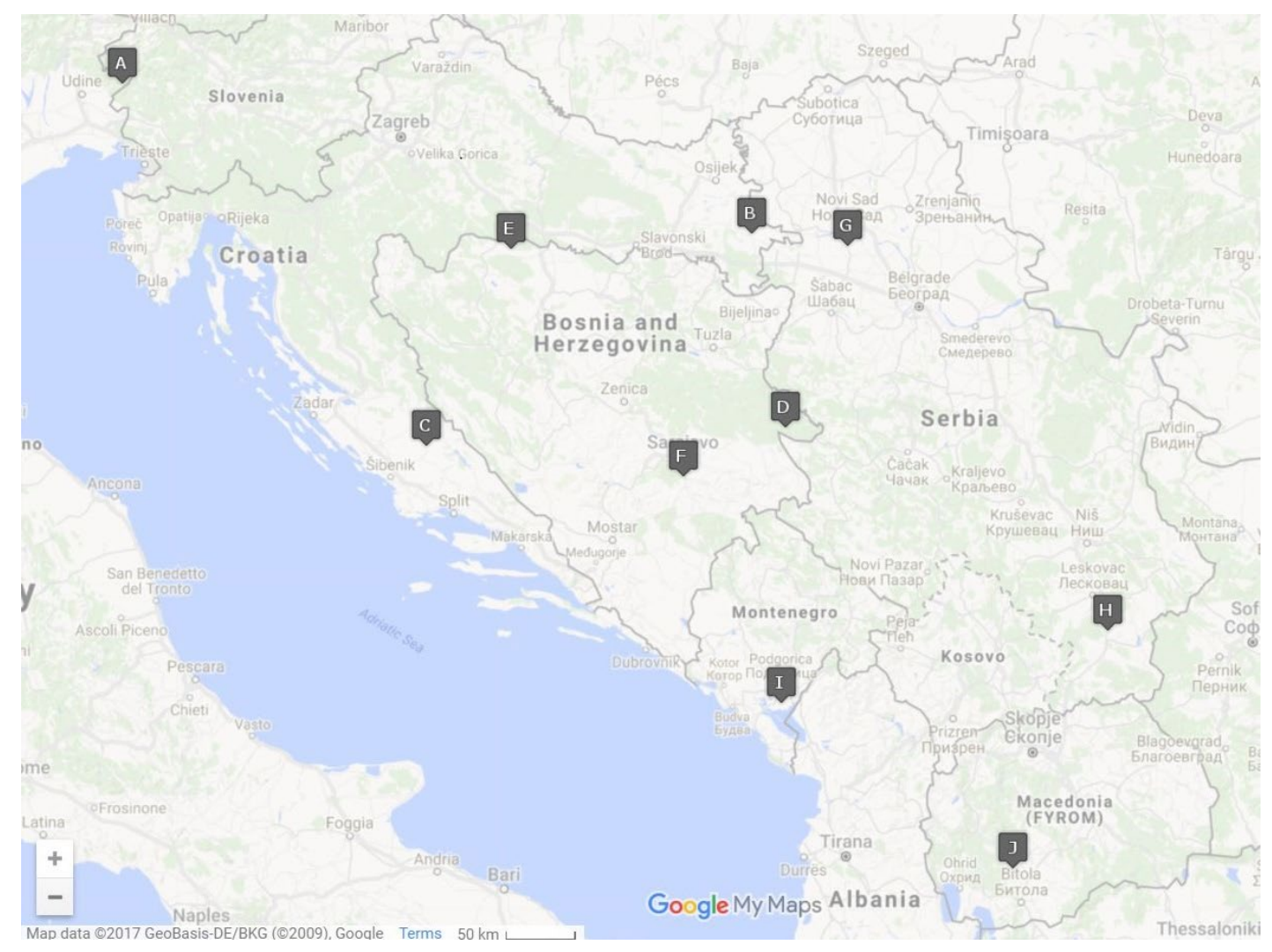

Source: Google Maps (2017)

The case studies of events included in this extreme case sample were constructed from a mixture of qualitative data, which were analysed together to develop a more comprehensive picture of each case study than could be gathered from one data source alone (Fielding \& 
Fielding, 1986; Decrop, 1999; Silverman, 2005). The main set of data used to develop the case studies came from interviews with key stakeholders associated with the events and their locations. Forty-one semi-structured (Kvale, 1996; Bryman \& Bell, 2007) interviews were conducted with curators or other responsible people of memorial centres, young intellectuals, university professors and researchers, and with WWII and Balkan war veterans. These interviews varied in length between forty-five minutes to 2 hours. Twenty relevant museums and memorial sites in the areas of these events were also visited for the purposes of observation and secondary data collection from archives and collections, e.g. Ovčara Memorial Center in Vukovar, the Srebrenica-Potočari Memorial and Cemetery, the Museum of Republika Srpska, the Jasenovac concentration camp, the Franja Partisan Hospital, State archive of Gorizia and others. In addition, as participants of commemorative events, the authors carried out direct observation, for example during the 100th anniversary of the Isonzo Front, and at WWII-related events in Slovenia and Croatia. Finally, this research made use of targeted media monitoring, using mainly national television and radio stations like HRT (Croatian Radio and Television), RTV (Slovenian Radio and Television), RTS (Serbian Radio and Television) and newspapers with an online presence including Delo, Jutarnji list, Politika and Oslobođenje.

A structured process of thematic content analysis was followed to analyse these diverse qualitative data sets. This form of qualitative data analysis breaks data down into smaller units linked to the literature and concepts involved in the research and allows for the identification of emergent themes and relationships that can be used to develop a rigorous analysis (Seale, 2004; Berg, 2007; Creswell, 2009). The literature reviewed above on collective memory was used to identify key themes within the data, to analyse the relationship between the events and the collective memories of the communities who participate in them. In particular, the data was analysed using the memory concepts associated with Halbwachs' (1992) structure of collective 
memory: history, historical memory and autobiographical memory. Nora's (1989) concept of the lieux due memoire was also applied in the analysis of the data through an evaluation of the contemporary political significance of the events in question. Taking these two elements together allows for a consideration of the inter-related memory 'content' of the event and its contemporary significance, for the evaluation of the role of the event in collective memory. In the discussion below, this is then linked to a judgement of the relative 'darkness' of the event, These two main areas were used to structure the analysis of the data and to develop the categorisation of the events that is presented below. The development of the categorisation also involved the comparison between the cases that made up the extreme case sample used for this paper, a strategy which can increase the validity of the findings of exploratory case study research (Yin, 2014; Silverman, 2005).

\section{Analysis and Discussion}

Data related to events included in the extreme case sample in table 2 were analysed using the key concepts associated with collective memory (Nora, 1989; Halbwachs, 1992) which were reviewed in previous sections of this paper. The aim of this was to develop a consideration of the 'darkness' of the events that went beyond the typology of the content of similar events created by Frost and Laing (2013), with the aim of generating fresh insights into these difficult to manage events.

Within this sample, events liked to 'historical memory' (after Halbwachs, 1992) are significant, as despite the fact that they commemorate events outside of the range of living memory, or within the memory of only a few people alive today in the region, they are invested with 
continuing political significance by memory actors (Milosevic, 2017) who seek to manipulate them for contemporary political ends. For example, event (A) in table 2 commemorates the enormous number of victims of the Isonzo front. However, despite the scale of the human tragedy involved, there are no possible participants in this event who could have experienced these battles; the commemorative event plays a role in contemporary society, but one that is linked to rituals of commemoration and heritage, rather than to autobiographical memory (Halbwachs, 1992). This event has recently included the concert of military brass bands Zbogom orožje (A Farewell to Arms) in Bovec, Tolmin in Kobarid in July 2017, which attracted locals, politicians, tourists and Slovenian media. Journalistic descriptions of the event such as 'a hundred years after the Isonzo front, a cruel sound of hatred, violence, and suffering is replaced with the sound of music' were common (Kjer so žvižgale krogle, danes odmeva godba, 2017; Močnik, 2017). Such events have a contemporary commemorative, educational as well as touristic purpose, but they are not significantly linked to the national identity of contemporary Slovenians.

From the same period, event (F) commemorates the assassination of the Archduke Franz Ferdinand of Austria in Sarajevo in 1914, an event which continues to be commemorated because of its wider political and historical significance, rather than because it had a specific local impact or because of its links to autobiographical memory (Halbwachs, 1992). In politically disunited Bosnia \& Herzegovina, two commemorative events are organised: one in Sarajevo, where high representatives of EU member states also participate, and another in Višegrad, where representatives of Serbs from Bosnia \& Herzegovina and Serbia are the main guests ('Sarajevo i Višegrad: 100 godina od rata', 2014; 'Stogodišnjica Sarajevskog atentata', 2014; 'Sto godina od Sarajevskog atentata', 2014). This exceptional case, where two different versions of the assassination and its consequences co-exist, is not completely in line with the 
general definition of Halbwachs (1992) as well as Confino (1997), which claims that heritage and traditions unify people, but supports Gugushvilli \& Kabachnik's (2017) analysis of the complexities of understanding the collective memory of large groups, with multiple competing narratives of the past. This example shows that the local/regional/national socio-political context must also be taken into account, for the analysis of contemporary commemorative events.

In contrast, a single event $(\mathrm{J})$ in table 2, commemorates the victory of the Macedonian people over the Ottomans in 1903, an event outside of the range of living memory, but which is celebrated additionally as a national and religious holiday as it coincides with the proclamation of the Macedonian Republic in 1944 and the day of Saint Elijah. This demonstrates how the gradual lessening of the links with autobiographical memory (Halbwachs, 1992) allows for commemorative events to take on Nora's (1989) function of the 'lieux de memoire', providing a focus for collective memory through their symbolic power. The slogan 'Our Macedonia without discrimination based on religion, ethnicity, gender and conviction' was the theme of all these events in 2017. Macedonian politicians, as the dominant memory actors (Milosevic, 2017) in this case, highlighted the importance of coexistence in the country, as well as international cooperation in the region and Europe (U Makedoniji obeležen nacionalni praznik Ilinden, 2017). Since the military conflict between Macedonians and Albanians in 2001, such national holidays and related events also fulfil a contemporary role of helping to maintain coexistence between nations and religions in Macedonia.

In common with the approaches taken by other authors in the categorisation of dark tourism and leisure (Strange and Kempa, 2003; Stone, 2006; Ryan \& Kohli, 2016; Powell et al., 2018), 
this paper aims to develop a categorisation of the relative darkness of commemorative events. From the perspective of collective memory, the 'darkest' of the events analysed in this research are those commemorative events where collective memories connected to conflict are linked to 'autobiographical memory' (Halbwachs, 1992), an approach that shares the temporal perspective of the many attempts to categorise the shades of dark tourism, where those attractions which draw on recent historical events for their content are regarded as 'darker' than those which draw on more historically distant, or mythical events. From this perspective, it is the manipulation of autobiographical memory by the 'memory makers' (Kansteiner, 2002) or dominant 'memory actors' (Milošević, 2017) which gives these events their particular contemporary political significance. Many such events are organized in the post-conflict areas of the former Yugoslavia, e.g. the anniversary of the military action "Oluja," (Storm) in Serbia (G), Srebrenica Memorial Day in Bosnia and Herzegovina (D) and Celebrations of the Victory and Homeland Thanksgiving Day and the Croatian Veterans Day Croatia (D). One of the main characteristics of these events is a strong emotional component related to the participation of veterans, survivors, relatives and others directly affected by the conflicts of the 1990s. Especially important are significant anniversaries, which attract the most media attention. These events serve to consolidate national identity and nationhood and are frequently subjected to political interference, which usually involves their capture within nationalist political narratives (Ivanov, 2009; Šuligoj, 2016, 2017a). The Curator of the Srebrenica-Potočari Memorial and Cemetery and personnel of the souvenir shop at Ovčara Memorial Center in Vukovar, who help in organising these events, expressed doubts in the capacity of these events to contribute to reconciliation as long as some war criminals continue to live in the local areas. Interestingly, multiple interview respondents were very critical towards the attitudes of political parties/high political representatives of countries in the region towards these events. 
Incidents such as the attack on the Serbian prime minister by a crowd of Bosnian Muslims with stones and water bottles at the $20^{\text {th }}$ anniversary commemorations of the Srebrenica massacre, can be understood only as consequence of the contested nature of the commemorative events described above ('Vučić napadnut i izviždan; Reakcije - napad na Vučića je napad na dostojanstvo žrtava', 2015; 'Majke Srebrenice" i Ćamil Duraković osudili napad na Vučića', 2015). In 2017 the Serbian Mayor of the Municipality of Srebrenica, invited the Serbian extremist and author of the book "Srebrenica - Lie and framing the Serb people", only a few days before the commemoration, to promote the book in Srebrenica. The Chairman of the commemoration Organizing Committee, described this action as creating divisions, insulting victims and minimizing genocide. This coincidence of the temporal proximity of specific occurrences of tragedy and suffering with contemporary political and ideological significance suggests a similar categorisation of the 'darkness' of commemorative events as that used by Stone (2006) in developing a categorisation of the darkness of the supply-side of dark tourism, of which dark events often form a part. This political and ideological component of commemorative events is what enables them to function as lieux de memoire (Nora 1989), with a broader social and cultural significance than that bestowed upon them solely by the autobiographical memories of those involved as participants.

Figure 2 below has been developed using the comparison of case studies sampled for this paper and building on the conceptual components of the collective memory approach, which allows for the mapping of commemorative events in a matrix with two axes. The first axis situates the event as drawing on one of three of Halbwach's (1992) categories of memory, as discussed above - history, historical or autobiographical. Each event that is included in this matrix was evaluated to assess which of these aspects of collective memory was dominant, when considering the content of the event. This evaluation was carried out through the analysis of 
key stakeholder interviews, data collected during site visits and media reports. The second axis describes the level of contemporary political significance attached to the event, to establish the degree to which the event functions as a lieux du memoire (Nora, 1989), which was evaluated primarily using data collected from the direct observation and media monitoring described in the methods section, above. Taken together, these two categorisations reflect Halbwachs (1992) conceptualisation of collective memory, that is, the social use of memory for contemporary ends, in this case through commemorative events (Halbwachs, 1992; Schuman \& Rogers, 2004; Breitwig, 2014; Garagazov, 2016). All 32 commemorative events that formed the original sample for this paper have been included plotted on this matrix, to develop a more robust categorisation, and are numbered as such. The memory type 'history' (Halbwachs, 1992) did not feature in the sample used for this study, which focused on twentieth century conflicts. However, a broader sample would have included, for example, the commemoration of the Battle of Kosovo in 1389, which plays a significant role in contemporary Serbian political culture (especially after Kosovo's proclamation of independence). There is an important dynamic temporal aspect to this mapping, which means that it is necessary to acknowledge the time in which it is applied. Events which commemorate aspects of conflicts and suffering that took place in WWII are currently included in the 'autobiographical memory' category for example, but as time passes and the veterans and other participants of that conflict die, these events will be re-categorised as belonging to the ‘historical memory’ category.

The management of all successful events requires engagement with stakeholders and the balancing of the requirements and operations of the events with stakeholders' perspectives and priorities (Quinn, 2009; Getz \& Page, 2016; Bladen et al., 2017) and where events intersect with political and policy issues, this need is often even more acute (Hall \& Rusher, 2004; Getz, 
2009). Despite this, the intersections between events, politics, communities and identity are some of the most under-researched topics in the events management literature (Mair \& Whitford, 2013), despite their prominence within the emerging Critical Events Studies field (Lamond \& Platt, 2016; Spracklen \& Lamond, 2016). Frost et al. (2009: 163) explain that commemorative events can have significance to groups of stakeholders outside of the usual 'corporatist model' due to their cultural and political significance. The increasing complexity of stakeholder management issues associated with these events is also included in figure 2, below.

Figure 2 - Dark Events in the Former Yugoslavia categorised using collective memory

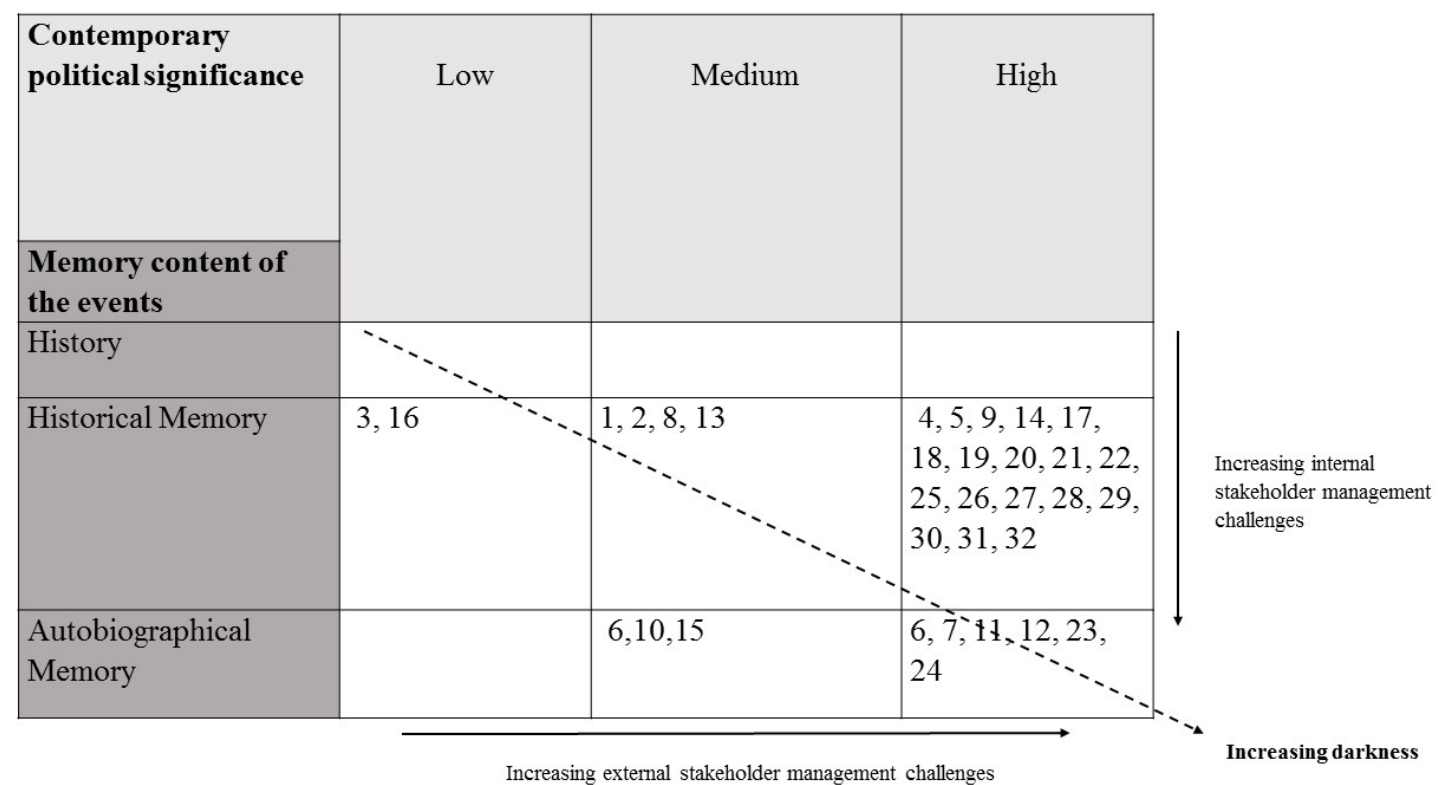

As explained in the discussion and analysis section, above, those events which draw on the most recent memory are regarded as the darkest, in line with similar categorisations of dark tourism and leisure which contain significant temporal elements in their categorisations (E.g. Stone, 2006). However, it is also important, from the perspective of collective memory (Nora, 1989; Halbwachs, 1992) to understand these events from the perspective of their function in 
contemporary society and the degree to which they act as a lieux du memoire for participants and other memory actors. The model in figure 2 allows for these different aspects of collective memory to be analysed side by side. This categorisation shows that, of the thirty two events that were analysed as part of this research, six are both based on autobiographical memory and involve a high degree of contemporary political significance and these are the darkest commemorative events in the region. A further three are also related to recent autobiographical memory, but have less contemporary significance, meaning that they are less dark, but still involve complex stakeholder management issues, with an emphasis on managing internal stakeholders. Eighteen have a high level of political significance, but draw on historical memory. These events are less dark than the first category of event, but involve complex eternal stakeholder management issues. Four events, which are based on historical memory and which have a medium level of political significance, are in the middle of this scale. These events will require sensitive stakeholder management, but do not present the complexity in these terms of the more dark events in this sample. Finally, two events are the least dark in this sample and will be the least complicated to manage concerning stakeholder engagement.

This paper has identified the often highly involved nature of political stakeholders in these types of events in the former Yugoslavia, suggesting that the increasing political significance of commemorative events will lead to increasing challenges for event managers in their relationships with key external stakeholders. The nature of many commemorative events means that the content and delivery of them needs to be managed sensitively in respect of participants and their families (Frew, 2012; Frost \& Laing, 2013). Figure 2 shows that the increasing complexity of these stakeholder management issues increases in relation to the type of memory that is involved in the commemoration and to the contemporary political significance of the event. Taken together, the types of memory involved and the political 
significance of a commemorative combine to indicate the degree to which the event plays a role in collective memory, that is to say, to what extent the events functions as a lieux de memoire in contemporary society. It is events which combine autobiographical memory and high political significance that can be regarded as the 'darkest' events, due to their link to near contemporary tragedy and suffering and their contemporary social significance, and it is the 'darkest' events which pose the most complex stakeholder management issues in their planning and delivery.

\section{Conclusions}

This paper has developed a new understanding of the relative darkness of commemorative events that are linked to tragedy and suffering, by using examples of the many such events that take place within the countries of the former state of Yugoslavia. In order to do this, the paper has drawn from the field of memory studies and, in particular, the concept of collective memory. Doing this drew attention to two key aspects of commemorative events. Firstly, the kind of memory that they draw on for their content and, secondly, the degree to which they have contemporary political significance. The contemporary social function of these events indicates the degree to which they are involved in the collective memory of the communities involved, and where these events also draw on recent autobiographical memory, then this paper has categorised these as the darkest. This adds a new perspective to the existing research on commemorative events, through the development of scale with which to measure their darkness, and by applying concepts from memory studies to do so. 
The history of Twentieth-century conflicts in the former Yugoslavia has meant that there are many commemorative events which draw on autobiographical memory and the very recent history of conflict also means that many events continue to have a strong political significance. Therefore, the region has lots of 'dark' events which pose significant management challenges. However, as the autobiographical content of commemorative lessens over time, some of the internal stakeholder management problems will too. As the region continues to develop however, managing external stakeholder relationships for these events will remain problematic due to their function as lieux de memoire within young states with increasingly nationalistic politics.

This work has a number of limitations that can be addressed in future research. Although care was taken to systematically develop a sample for this paper, the wide range of events and their heterogeneity in location, period of historical reference and size, meant that a smaller extreme case sample was chosen for this research. Future research in the former Yugoslavia should seek to broaden this sample and to conduct country-by-country research which will allow for greater depth of analysis. In addition, future research should seek to apply this understanding of the darkness of commemorative events in countries outside of the Western-Balkans region, to investigate to what extent local political and social contexts influence the role of commemorative events in collective memory. 


\section{References}

Akrivoulis, D.E. (2017). Memory, Forgiveness and Unfinished Justice in the Former Yugoslavia. Journal of Balkan and Near Eastern Studies. 19 (4). 1-22.

Anderson, B. (2006). Imagined communities: Reflections on the origin and spread of nationalism. London. Verso Books.

Ashworth, G., Hartmann, R. (2005).The management of horror and human tragedy. In: Ashworth, G. \& R. Hartmann (eds.). Horror and Human Tragedy Revisited: The Management of Sites of Atrocities for Tourism. New York, Cognizant Communications Corporation. 253-262.

Ashworth, G. J., \& Isaac, R. K. (2015). Have we illuminated the dark? Shifting perspectives on 'dark' tourism. Tourism Recreation Research, 40(3), 316-325

Barash, J.A. (2016). Virtual experience, collective memory, and the configuration of the public sphere through the mass media. The example of Ex-Yugoslavia. Configurações. Revista de sociologia, (17): 11-29.

Bartolini, S. (2008). Fascismo antislavo: il tentativo di 'bonifica etnica' al confine nord orientale. Pistoia: ISRPt. 
Bartlett, F. C. (1995). Remembering: A Study in Experimental and Social Psychology. Cambridge: Cambridge University Press.

Berg, B.L. (2007) Qualitative research methods for the social sciences 6th ed., Boston: Pearson - Allyn \& Bacon

Bevc, B. (2009). Življenje v prvi Jugoslaviji s poudarkom na srbsko-hrvaškem sporu. Glasnik Slovenskega etnološkega društva. 49 (1/2). 72-79.

Biran, A., \& Poria, Y. (2012). Re-conceptualising dark tourism. In R. Sharpley, \& P.Stone (Eds.), The contemporary tourism experience: Concepts and consequences. London: Routledge. 62-79

Bladen, C., Kennell, J., Abson, E. \& Wilde, N. (2017) Events Management: An Introduction $2^{\text {nd }} E d$. London: Routledge

Boukas, N., Ziakas, V. and Boustras, G., 2013. Olympic legacy and cultural tourism: Exploring the facets of Athens' Olympic heritage. International Journal of Heritage Studies, 19(2). 203-228. 
Breitweg, M. 2014. Collective memory after violent conflicts: Can collective amnesia ever be a sustainable option for reconciliation initiatives? Paper presented at the 5th ECPR Graduate Student Conference, Innsbruck. 3-5 July, 2014.

Bryant, C.D. (Ed) (2011) The Routledge Handbook of Deviant Behaviour. London. Routledge.

Bryman, A. \& Bell, E. (2007) Business research methods 2nd ed., Oxford: OUP

Colmeiro, J. (2011). A Nation of Ghosts?. 452 F: revista de teoría de la literatura y literatura comparada, (4). 17-34.

Commission of the European Communities, Eurostat \& Organisation for Economic Cooperation and Development \& World Tourism Organization \& United Nations Statistics Division (2001). Tourism Satellite Account: Recommended Methodological Framework. Retrieved 1 March 2018, from https://unstats.un.org/unsd/publication/SeriesF/SeriesF_80e.pdf.

Confino, A. (1997). Collective Memory and Cultural History: Problems of Method. The American Historical Review. 102 (5). 1386-1403. 
Creswell, J. W. (2009) Research Design: Qualitative, Quantitative and Mixed Methods Approaches. London. Sage

Dan, P. (2017). The return of the Repressed: Collective Memory and the Revival of Nationalism and Authoritarian Politics. Paper presented at the ASN World Convention. Columbia University. 4-6 May 2017

Dann, G. M. S. (1994). Tourism: The nostalgia industry of the future. In W. Theobald (Ed.), Global tourism: The next decade. Oxford: Butterworth Heinemann. 55-67

David, A.R., (2012). Embodied migration: Performance practices of diasporic Sri Lankan Tamil communities in London. Journal of Intercultural Studies, 33(4). 375-394.

de Saint-Laurent, C., 2017. Memory acts: A theory for the study of collective memory in everyday life. Journal of Constructivist Psychology. 1-15.

Decrop, A. (1999) Triangulation in Tourism Research in Annals of Tourism Research. 20 (1). $157-161$

Dežman, J. (2014). Preseganje travmatskih bremen titoizma. Bogoslovni vestnik. 4(74). 611638. 
Draper, J., Young Thomas, L., \& Fenich, G. G. (2018). Event management research over the past 12 years: What are the current trends in research methods, data collection, data analysis procedures, and event types?. Journal of Convention \& Event Tourism. 19 (1). 3-24.

Dukovski, D. (1998). Fašizam u Istri, 1918.-1943. Pula: Histria Croatica C.A.S.H.

Dukovski, D. (2008). Dva egzodusa: hrvatski (1919.-1941.) i talijanski (1943.-1955.). Zbornik Radova Zavoda Za Znanstveni I Umjetnički Rad Hrvatske Akademije Znanosti I Umjetnosti U Splitu. 15(Prosinac 2008). 129-165.

Dunkley, R. A., Morgan, N. \& S. Westwood (2011). Visiting the trenches: Exploring meanings and motivations in battlefi eld tourism. Tourism Management, 32, 4, 860-868.

Ferenc, M. (2012). Prekopi žrtev iz prikritih grobišč: (1991-2011). Ljubljana: Znanstvena založba Filozofske fakultete.

Ferenc, M. (2013). Huda Jama (grave pit): coal mine mass massacre (May, June 1945). Ljubljana: Znanstvena založba Filozofske fakultete.

Ferree, C. (2017). Full Listing of Concentration Camps. Retrieved 29 August 2017, from 
http://www.jewishvirtuallibrary.org/full-listing-of-concentration-camps\#yugo

Fielding, N. G., \& Fielding, J. L. (1986). Linking data: the articulation of qualitative and quantitative methods in social research. London. Sage

Flyvbjerg, B. (2006). Five misunderstandings about case-study research. Qualitative Inquiry. 12(2). 219-245.

Foley, M., Lennon, J. (1996): Editorial: Heart of darkness. International Journal of Heritage Studies, (2) 4. 195-197.

Foley, M., Lennon, J. (1997). Dark Tourism - An Ethical Dilemma. In: Foley, M., Lennon, J. \& G. A. Maxwell (eds.). Hospitality, Tourism and Leisure Management: Issues in Strategy and Culture. Scarborough, Cassell. 143-164.

Fox, D., Gouthro, M. B., Morakabati, Y., \& Brackstone, J. (2014). Doing Events Research: From Theory to Practice. London. Routledge.

Frew, E. and White, L. (2015). Commemorative Events and National Identity: Commemorating Death and Disaster in Australia. Event Management: An International Journal. 19(4). 509-524. 
Frew, E. A. (2012). Interpretation of a sensitive heritage site: The Port Arthur Memorial Garden, Tasmania. International Journal of Heritage Studies. 18(1). 33-48.

Frost, W., Wheeler, F., \& Harvey, M. (2009). 'Commemorative events: sacrifice, identity and dissonance.' In Ali-Knight, J., Robertson, M., Fyall, A. \& Ladkin, A. (eds.) International Perspectives of Festivals and Events. London. Routledge. 161-171.

Frost, W., \& Laing, J. (2013). Commemorative events: Memory, identities, conflict. London. Routledge.

Kjer so žvižgale krogle, danes odmeva godba (2017). Foto. Retrieved 5 November 2017, from http://www.rtvslo.si/prva-svetovna-vojna/foto-kjer-so-zvizgale-krogle-danes-odmevagodba/427049

Gapps, S. (2009). Mobile monuments: A view of historical reenactment and authenticity from inside the costume cupboard of history. Rethinking History. 13(3). 395-409

Garagozov, R., (2016). Painful collective memory: Measuring collective memory affect in the Karabakh conflict. Peace and Conflict: Journal of Peace Psychology, 22(1). 28-35

Getz, D. (2005). Event management \& event tourism $2^{\text {nd }}$ ed. New York: Cognizant Communication. 
Getz, D. (2008). Event tourism: Definition, evolution, and research. Tourism Management, $29(3), 403-428$.

Getz, D. (2009). Policy for sustainable and responsible festivals and events:

Institutionalization of a new paradigm. Journal of Policy Research in Tourism, Leisure and Events. 1(1). 61-78.

Getz, D., \& Page, S. J. (2016) Progress and prospects for event tourism research. Tourism Management. 52. 593-631.

Getz, D. \& Page, S. (2016) Event Studies: Theory, Research and Policy for Planned Events. Abingdon. Routledge

Google Maps (2017) Dark Events in the Former Yugoslavia [author created]

Available from: https://drive.google.com/open?id=1gPTCb84Nsg XTUUoSUF-qSef$\underline{87 \text { znuU2\&usp }=\text { sharing }}$

Accessed $7^{\text {th }}$ March 2018

Gugushvili, A., Kabachnik, P., \& Kirvalidze, A. (2017). Collective memory and reputational politics of national heroes and villains. Nationalities Papers, 45(3), 464-484. 
Gulić, M. (2014). Kraljevina Jugoslavija i Dunav: dunavska politika jugoslovenske kraljevine 1918-1944. Beograd: Institut za savremenu istoriju.

Halbwachs, M., (1992). On Collective Memory. Chicago. University of Chicago Press.

Hall, J., Basarin, V.J. and Lockstone-Binney, L. (2010). An empirical analysis of attendance at a commemorative event: Anzac Day at Gallipoli. International Journal of Hospitality Management. 29(2). 245-253.

Hall, R. C. (2000). The Balkan Wars 1912-1913: Prelude to the First World War. London: Routledge.

Hall, M. and Rusher, K. (2004). Politics, public policy and the destination. Festival and events management. 217-231.

Hasic, T. (2004). Ethnic Conflict and the Right to Return of Limbo Diasporas: Multifaceted Reflections on the Case of BiH. Migracijske I Etničke Teme. 20(1). 29-49.

Hogan, J. (2009). Gender, race and national identity: Nations of flesh and blood. New York: Routledge. 
Hribar, S. (1988). Nepokopana revolucija. Nova revija. 7(77). 1372-1377.

Ivanov, S. (2009). Opportunities for developing communist heritage tourism in Bulgaria. Tourism. 57 (2). 177-192.

Kansteiner, W. (2002). Finding meaning in memory: A methodological critique of collective memory studies. History and theory. 41(2). 179-197.

Karge, H. (2009). Mediated remembrance: local practices of remembering the Second World War in Tito's Yugoslavia. European Review of History-Revue européenne d'histoire, 16(1) $.49-62$.

Kemper, E. A., Stringfield, S., \& Teddlie, C. (2003). Mixed methods sampling strategies in social science research in Tashakori, a. \& Teddie, C. (eds.). Handbook of mixed methods in social and behavioral research. London. Sage. 273-296.

Kvale, S. (1996). InterViews: An introduction to qualitative research interviewing. Thousand Oaks. Sage.

La Storia. (2017). La Storia. Retrieved 29 August 2017, from http://www.risierasansabba.it/la-storia/ 
Lamond, I. R., \& Platt, L. (Eds.). (2016). Critical event studies: Approaches to research. London. Palgrave Macmillan.

Lampe, J. (2014). Balkans into Southeastern Europe, 1914-2014: A Century of War and Transition. Basingstoke, New York: Palgrave Macmillan.

Lavrakas, P. J. (2008). Encyclopedia of survey research methods. London. Sage.

Lemelin, H., Whyte, R., K., Johansen, K., Higgins Desbiolles, F., Wilson, C., \& Hemming, S. (2013). Conflicts, battlefields, indigenous peoples and tourism: addressing dissonant heritage in warfare tourism in Australia and North America in the twenty-first century. International Journal of Culture, Tourism and Hospitality Research. 7(3). 257-271.

Lennon, J., \& Foley, M. (2000). Dark Tourism: the attraction of death and disaster, Thomson. London.

Liao, D-Y. C. (2016). Space and Memory in the Huashan Event. In Lamond, I.R. and Platt, L. (eds.). Critical event studies: Approaches to research. London. Springer. 109-130

Light, D. (2017). Progress in dark tourism and thanatourism research: An uneasy relationship with heritage tourism. Tourism Management. 61. 275-301 
Lincoln, Y. S. (1995). Emerging criteria for quality in qualitative and interpretive research. Qualitative Inquiry. 1(3). 275-289.

Lorenz, G. (2010) Unstuck in time. Or the sudden presence of the past. in Tilmans, K., van Vree, F. and Winter, J.M. (eds.) Performing the past: memory, history, and identity in modern Europe. Amsterdam University Press. 67-104

Luthar, O. (2008). The Slovenes and the Kingdom of Serbs, Croats, and Slovenes. In O. Luthar (Ed.), The land between: a history of Slovenia. Frankurt am Main: Peter Lang, 385399

Mair, J., \& Whitford, M. (2013). An exploration of events research: event topics, themes and emerging trends. International Journal of Event and Festival Management, 4(1), 6-30.

"Majke Srebrenice" i Ćamil Duraković osudili napad na Vučića (2015). RTS. Retrieved 5 November 2017, from: http://www.rts.rs/page/stories/sr/story/11/region/1974676/majke$\underline{\text { srebrenice-i-camil-durakovic-osudili-napad-na-vucica.html }}$

Maksimović, M. (2017). Unattainable past, unsatisfying present-Yugonostalgia: an omen of a better future?. Nationalities Papers, 45 (6). 1066-1081. 
Marijan, D. (2016). From people's liberation war and revolution to antifascist struggle. Review of Croatian History. XII(1). 155-182.

Marsetič, R. (2013). Analisi dell'apparato militare austro-ungarico a Pola durante la Prima guerra mondiale. Atti. XLII (1). 483-520.

McQuaid, S. D. (2017). Parading memory and re-member-ing conflict: Collective memory in transition in Northern Ireland. International Journal of Politics. Culture, and Society, 30(1). $23-41$.

Miles, W. (2002). Auschwitz: Museum interpretation and darker tourism. Annals of Tourism Research. 29(4). 1175-1178.

Milošević, A. (2017). Historicizing the present: Brussels attacks and heritagization of spontmemorials. International Journal of Heritage Studies. 24 (1).1-13.

Možina, J. (2016). Začetki oboroženih oddelkov protirevolucionarnega tabora v Ljubljanski pokrajini. Doctoral Dissertation. Univerza v Ljubljani, Filozaofska fakulteta, Ljubljana.

Močnik, B. (2017). Sto let od orožja do radosti. Retrieved 5 November, from http://www.delo.si/novice/slovenija/sto-let-od-orozja-do-radosti.html 
Myers, M. D. (2013). Qualitative Research in Business and Management. London. Sage.

Nanda, S. (2004). South African museums and the creation of a new national identity.

American Anthropologist. 106. 379-385.

Nora, P. (1989). Between memory and history: Les lieux de mémoire. Representations.7-24.

Olick, J. (2007a) 'Collective Memory' in Darity, W. (ed) International Encycopledia of the Social Sciences $2^{\text {nd }}$ ed, New York. Macmillan Refence Library. 7-8.

Olick, J. K. (2007b). The politics of regret: On collective memory and historical responsibility. Oxon, UK: Routledge.

Onwuegbuzie, A. J., \& Leech, N. L. (2007). Sampling designs in qualitative research: Making the sampling process more public. The qualitative report, 12(2). 238-254.

Patton, M. Q. (2005). Qualitative Research. London. John Wiley \& Sons, Ltd.

Perović, B. (2006). Luka Pula austrougarskog doba (Odsjaj grada u zaljevu 1850. - 1918.). In M. Černi (Ed.), Iz povijesti Pulske luke. Zbornik radova (pp. 70-191). Pula. Lučka uprava. 70-191 
Pirjevec, J. (1982). La fase finale della violenza fascista: i retroscena del processo Tomažič. Qualestoria: bollettino dell'istituto regionale per la storia del movimento di liberazione nel Friuli-Venezia Giulia. 10(2). 75-94.

Pirjevec, J. (2001). Bazoviški spomin. 2000: revija za krščanstvo in kulturo. 231-233.

Pirjevec, J. (2016). Benito Mussolini in Slovenci. Acta Histriae. 24(2). 721-730.

Podoshen, J. S., \& Hunt, J. M. (2009). Animosity, collective memory, rumor and equity restoration: Consumer reactions to the Holocaust. Consumption, Markets and Culture, 12(4), 301-327.

Podoshen, J. S.; Hunt, J. M. (2011). Equity restoration, the Holocaust and tourism of sacred sites. Tourism Management, 32 (6). 1332-1342.

Podoshen, J. (2013). Dark tourism motivations: Simulation, emotional contagion and topographic comparison. Tourism Management. (35). 263-271

Potts, T. J. (2012). 'Dark tourism' and the 'kitchification' of 9/11. Tourist Studies. 12 (3). 232-249. 
Powell, R., Kennell, J., \& Barton, C. (2018). Dark Cities: A dark tourism index for Europe's tourism cities, based on the analysis of DMO websites. International Journal of Tourism Cities. 4(1). 4-21.

Putnik, V. (2016). Second World War monuments in Yugoslavia as witnesses of the past and the future. Journal of Tourism and Cultural Change. 14(3). 206-221.

Quinn, B. (2009). Festivals, events and tourism. In Jamal, T (ed.). Sage Handbook of Tourism Studies. London. Sage

Ramet, S.P. (2013). Memory and identity in the Yugoslav successor states. Nationalities Papers, 41(6). 871-881.

Rekść, M. (2016). Post-Yugoslav Collective Memory: Between National and Transnational Myths. Polish Political Science Yearbook, 45, 73-84.

Rojek, C. (1993). Ways of Escape. Basingstoke. Macmillan.

Ryan, C., and Kohli, R., (2006) The Buried village, New Zealand - An example of dark tourism? Asia Pacific Journal of Tourism Research. 11 (3). 211-226 
Sather-Wagstaff, J. (2011). Heritage that hurts: Tourists in the memoryscapes of September 11 (Vol.4) . Walnut Creek. Left Coast Press.

Sarajevo i Višegrad: 100 godina od rata (2014). Mondo. Retrieved 5 November 2017, from http://mondo.ba/a489863/Info/BiH/Sarajevo-i-Visegrad-100-godina-od-rata.html

Saunders, M., Lewis, P., \& Thornhill, A. (2009). Research Methods for Business Students. London. FT-Prentice Hall

Schuman, H., \& Rodgers, W. L. (2004). Cohorts, chronology, and collectivememories. Public Opinion Quarterly. 68. 217-254.

Seale, C. (Ed.). (2004). Researching Society and Culture. London. Sage.

Seaton, A.V. (1996). "Guided by the dark: from thanatopsis to thanatourism" International Journal of Heritage Studies. 2(4). 234-244.

Seaton, A. V. (1999). War and Thanatourism: Waterloo 1815-1914. Annals of Tourism Research. 26. 130-158. 
Silverman, D. (2005) Doing Qualitative Research, London. Sage

Skillen, F. and Osborne, C., (2015). It's Good to Talk: Oral History, Sports History and Heritage. The International Journal of the History of Sport, 32(15). 1883-1898.

Slade, P. (2003). Gallipoli Thanatourism: The Meaning of ANZAC. Annals of Tourism Research, 30 (4). 779-794.

Sol, H., de Brito, M. P., Coelho, J. P., Figueira, L. M., Pratt, C., \& Lopes, E. R. (2017). Rooting a new event in its place: the case of Festa Templária, Tomar, Portugal. International Journal of Event and Festival Management, 8(3), 324-345.

Smith, O. (2014) Contemporary Adulthood and the Night Time Economy. London. Palgrave.

Spracklen, K. (2013). Leisure, Sports and Society. Basingstoke: Palgrave.

Spracklen, K. and Lamond, I.R., (2016). Critical Event Studies. London. Routledge.

Spomen područje Jasenovac. (2017). Jasenovac. Retrieved 29 August 2017, from http://www.jusp-jasenovac.hr/Default.aspx?sid=5021 
Stake, R. (2008). Qualitative case studies. In N. K. Denzin \& Y. S. Lincoln (Eds.). Strategies of Qualitative Inquiry ( $3^{\text {rd }}$ ed). Los Angeles. Sage. 119-149

Stebbins, R. A., Rojek, C., \& Sullivan, A. M. (2006). Special issue: Deviant leisure. Leisure/Loisir, 30(1). 3-305

Stogodišnjica Sarajevskog atentata (2014, Jun 28). B92. Retrieved 5 November 2017, from http://www.b92.net/info/vesti/index.php?yyyy=2014\&mm=06\&dd=28\&nav id=868941

Sto godina od Sarajevskog atentata (2014). RTS. Retrieved 5 November 2017, from http://www.rts.rs/page/stories/sr/story/125/drustvo/1635169/sto-godina-od-sarajevskog$\underline{\text { atentata.html }}$

Stone, P. (2006). “A Dark Tourism spectrum: towards a typology of death and macabre related tourist sites, attractions and exhibitions". Tourism. 54(2). 145-160

Stone, P. R. (2005). Dark tourism: an old concept in a new world. Tourism Magazine. Retrieved on $17^{\text {th }}$ November 2017, from http://works.bepress.com/philip_stone/26

Stone, P. R. (2006). A Dark Tourism Spectrum: towards a typology of death and macabre related tourist sites, attractions and exhibitions. Tourism: An Interdisciplinary International Journal. 54 (2). 145-160. 
Stone, P. R. (2012). Dark Tourism and Significant other Death: Towards a Model of Mortality Mediation. Annals of Tourism Research. 39 (3). 1565-1587

Stone, P. (2013). Dark tourism scholarship: a critical review. International Journal of Culture, Tourism and Hospitality Research, 7(3), 307-318.

Stone, P., Sharpley, R. (2008). Consuming dark tourism: A Thanatological Perspective. Annals of Tourism Research, 35 (2). 574-595

Stone, P.R. and Sharpley R. (2013) 'Deviance, Dark Tourism and 'Dark Leisure': Towards a (re)configuration of morality and the taboo in secular society'. In S. Elkington and S. Gammon (Eds). Contemporary Perspectives in Leisure: Meanings, Motives and Lifelong Learning. Abingdon. Routledge.

Strange, C., \& Kempa, M. (2003). Shades of dark tourism: Alcatraz and Robben Island. Annals of tourism research, 30(2), 386-405.

Šuligoj, M. (2016a). 'Memories of war and warfare tourism in Croatia'. Annales. Series Historia et Sociologia, 26(2). 259-270. 
Šligoj, M., (2016b). 'Impact of the great war on the conditions for the development of the hospitality industry in gorizia/görz/gorica and its surroundings'. Historický časopis, 3(64). 431-449.

Šuligoj, M., (2017a). 'Warfare tourism: an opportunity for Croatia?'. Economic researchEkonomska istraživanja, 30(1).439-452.

Šuligoj, M. (2017b). Memorials of the Balkan conflict as tourist (heritage) sites. In Rangus, M., Gorenak, M., Brumen, B. (eds). Sustainability in Tourism and Regional Development. Newcastle upon Tyne: Cambridge Scholars Publishing. 45-55

Tunbridge, J. E., \& Ashworth, G. J. (1996). Dissonant heritage: the management of the past as a resource in conflict. John Wiley \& Sons.

U Makedoniji obeležen nacionalni praznik Ilinden (2017). B92. Retrieved 5 November 2017, from http://www.b92.net/info/vesti/index.php?yyyy $=2017 \& \mathrm{~mm}=08 \& d d=02 \&$ nav category $=167 \&$ $\underline{\text { nav id }=1289187}$

United Nations. (1951) No. 1021, Convention on the Prevention and Punishment of the Crime of Genocide. Retrieved 5 November 2017, from https://treaties.un.org/doc/publication/unts/volume\%2078/volume-78-i-1021-english.pdf 
U.S. Department of State (1995). Dayton Accords. Retrieved 1 September 2017, from https://www.state.gov/p/eur/rls/or/dayton/

Veal, A. J. (2007). Research Methods for Leisure and Tourism. London. Pearson.

Vučić napadnut i izviždan; Reakcije - napad na Vučića je napad na dostojanstvo žrtava (2015). HRT. Retrieved 5 November 2017, from http://vijesti.hrt.hr/291794/vucicevaprisutnost-izazvala-burno-negodovanje

Williams, D.J. (2009) Deviant Leisure: Rethinking 'The Good, the Bad, and Ugly'. Leisure Sciences. 31 (2). 207-213.

Winter, C. (2011). Battlefield Visitor Motivations: Explorations in the Great War Town of Ieper, Belgium. International Journal of Tourism Research, 13 (2). 164-176.

Yan, B.-J., Zhang, J., Zhang, H.-L., Lu, S.-J., \& Guo, Y.-R. (2016). Investigating the motivation-experience relationship in a dark tourism space: A case study of the Beichuan earthquake relics, China. Tourism Management. 53. 108-121. 
Yankholmes, A., \& McKercher, B. (2015). Understanding visitors to slavery heritage in Ghana. Tourism Management, 51(12), 22-32.

Yin, R. K. (2014). Case study research and applications: Design and Methods. London. Sage

Zvijer, N. (2014). Presenting (Imposing) Values through Films. The Case of the Yugoslav Partisan Films. Images, 2(2). 1-21. 
Table 1: Typology of dark commemorative events

\begin{tabular}{|l|l|}
\hline Type & Example of event \\
\hline Dark exhibitions & $\begin{array}{l}50^{\text {th }} \text { anniversary of the Enola } \\
\text { Gay dropping the atom bomb } \\
\text { on Japan, }\end{array}$ \\
\hline $\begin{array}{l}\text { Dark re-enactments } \\
\text { remembrance }\end{array}$ & $\begin{array}{l}\text { Annual re-enactment of the } \\
\text { Battle of Little Bighorn, USA }\end{array}$ \\
\hline $\begin{array}{l}\text { Memorial services, opening of } \\
\text { memorials, concerts, } \\
\text { performances }\end{array}$ & $\begin{array}{l}\text { Anzac day at Gallipoli, } \\
\text { Turkey }\end{array}$ \\
\hline $\begin{array}{l}\text { Significant anniversaries (e.g. } \\
\text { centenaries })\end{array}$ & $\begin{array}{l}\text { Bicentenary of the French } \\
\text { Revolution }\end{array}$ \\
\hline $\begin{array}{l}\text { Parades, marches, processions } \\
\text { Festivals }\end{array}$ & $\begin{array}{l}\text { Bloody Sunday March, } \\
\text { Northern Ireland }\end{array}$ \\
\hline
\end{tabular}

Source: Adapted from Laing \& Frost (2013) 
Figure 1 -Location of sampled commemorative events in the former Yugoslavia

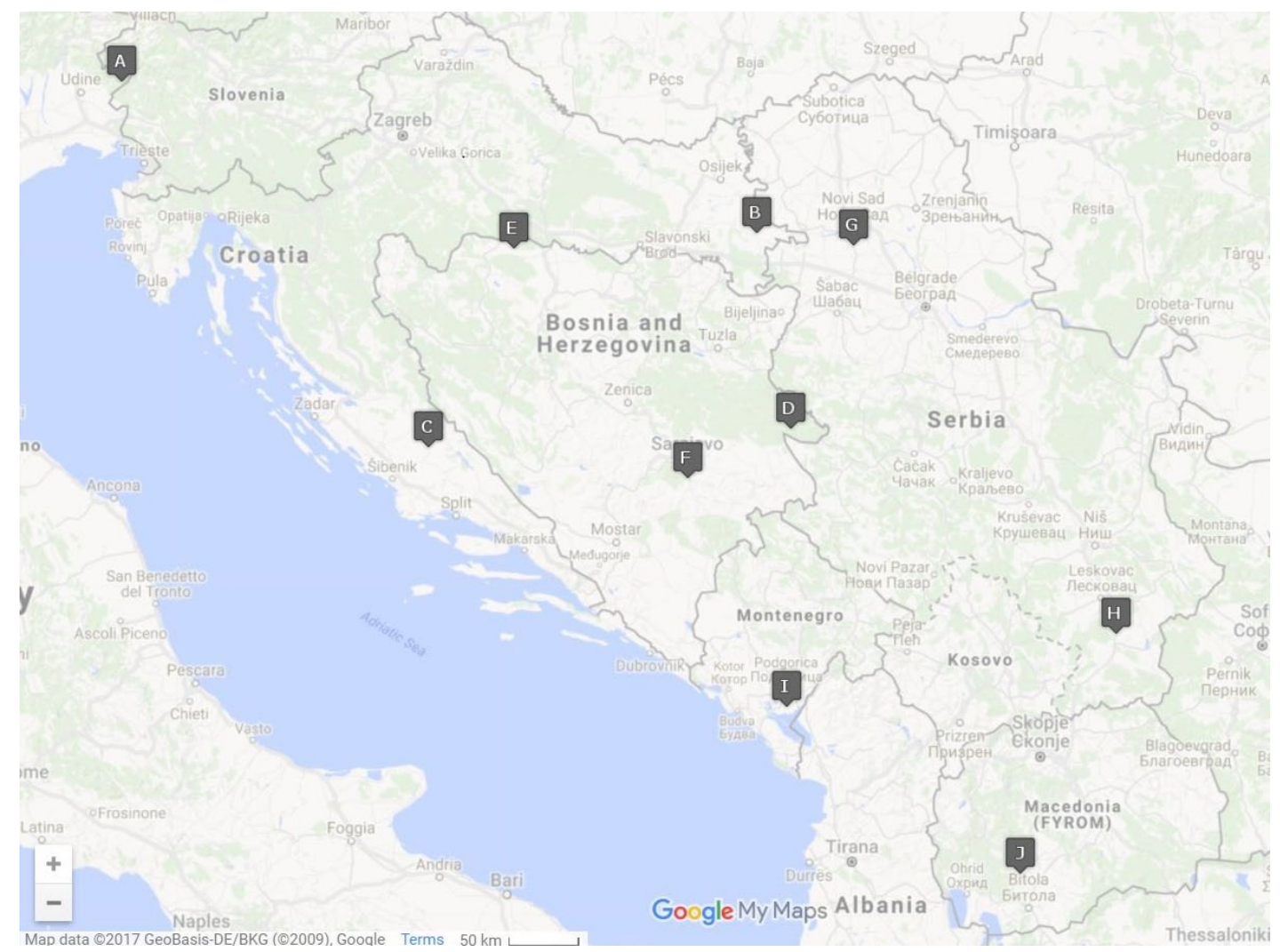

Source: Google Maps (2017) 
Table 3 - Sample of commemorative events in the Former Yugoslavia

\begin{tabular}{|c|c|c|c|c|c|}
\hline Sample & State / Event & Type ${ }^{\text {ii }}$ & $\begin{array}{l}\text { Micro } \\
\text { location }\end{array}$ & Background & $\begin{array}{l}\text { Estimated Number of } \\
\text { attendees }\end{array}$ \\
\hline \multicolumn{6}{|c|}{ Slovenia } \\
\hline $3(\mathrm{~A})$ & $\begin{array}{l}\text { Memorial events } \\
\text { associated with } \\
\text { the Isonzo front }\end{array}$ & SA & Kobarid & $\begin{array}{l}\text { WWI: Isonzo } \\
\text { front (1915-1917) } \\
\text { along the current } \\
\text { Italian-Slovenian } \\
\text { border }\end{array}$ & c. $1,000-2,000$ \\
\hline \multicolumn{6}{|l|}{ Croatia } \\
\hline $6(\mathrm{~B})$ & $\begin{array}{l}\text { Day of } \\
\text { Remembrance for } \\
\text { the victims of } \\
\text { Vukovar }\end{array}$ & $\begin{array}{l}\text { NDR, } \\
\text { PMP }\end{array}$ & Vukovar & $\begin{array}{l}\text { Homeland war in } \\
1990 \mathrm{~s}\end{array}$ & c. 64,000 \\
\hline $7(\mathrm{C})$ & $\begin{array}{l}\text { Celebrations of } \\
\text { the Victory and } \\
\text { Homeland } \\
\text { Thanksgiving } \\
\text { Day and the } \\
\text { Croatian Veterans } \\
\text { Day }\end{array}$ & $\begin{array}{l}\text { NDR, } \\
\text { PMP }\end{array}$ & Knin & $\begin{array}{l}\text { Homeland war in } \\
1990 \mathrm{~s}\end{array}$ & c. 8,000 \\
\hline \multicolumn{6}{|c|}{ Bosnia \& Herzegovina } \\
\hline $12(\mathrm{D})$ & $\begin{array}{l}\text { Srebrenica } \\
\text { Memorial Day }\end{array}$ & $\begin{array}{l}\text { NDR, } \\
\text { MSP }\end{array}$ & Potočari & $\begin{array}{l}\text { Mass killings in } \\
\text { Srebrenica and its } \\
\text { surroundings in } \\
\text { July } 1995\end{array}$ & $\begin{array}{l}\text { c. } 20,000-50,000 \text { (this has } \\
\text { varied enormously due to } \\
\text { the timing of significant } \\
\text { anniversaries) }\end{array}$ \\
\hline
\end{tabular}




\begin{tabular}{|c|c|c|c|c|c|}
\hline $14(\mathrm{E})$ & $\begin{array}{l}\text { Commemoration } \\
\text { of Jasenovac } \\
\text { victims }\end{array}$ & MSP & $\begin{array}{l}\text { Donja } \\
\text { Gradina }\end{array}$ & $\begin{array}{l}\text { WWII: } \\
\text { commemoration } \\
\text { of the Serb } \\
\text { victims of the } \\
\text { camp }\end{array}$ & c. 2,000 \\
\hline $16(\mathrm{~F})$ & $\begin{array}{l}\text { The anniversary } \\
\text { of the } \\
\text { assassination in } \\
\text { Sarajevo }\end{array}$ & SA & Sarajevo & $\begin{array}{l}\text { WWI: The } \\
\text { assassination of } \\
\text { Archduke Franz } \\
\text { Ferdinand of } \\
\text { Austria }\end{array}$ & c. 30,000 \\
\hline \multicolumn{6}{|l|}{ Serbia } \\
\hline $23(\mathrm{G})$ & $\begin{array}{l}\text { Anniversary of } \\
\text { the military - } \\
\text { police action } \\
\text { "Oluja," (Storm) }\end{array}$ & MSP & Novi Sad & $\begin{array}{l}\text { Balkan conflict in } \\
\text { 1990s: } \\
\text { Commemoration } \\
\text { of Serbian } \\
\text { victims in Croatia }\end{array}$ & c. 30,000 \\
\hline $\begin{array}{l}24 \\
\text { (H) }\end{array}$ & $\begin{array}{l}\text { Anniversary of } \\
\text { NATO bombing }\end{array}$ & MSP & Grdelica & $\begin{array}{l}\text { Balkan conflict in } \\
1990 \mathrm{~s}\end{array}$ & C, $2,000-5,000$ \\
\hline \multicolumn{6}{|c|}{ Montenegro } \\
\hline 25 & $\begin{array}{l}\text { Ceremonies of the } \\
\text { Day of Victory } \\
\text { over fascism in } \\
\text { World War II }\end{array}$ & NDR & Podgorica & End of WWII & c. 2,000 \\
\hline \multicolumn{6}{|c|}{ FYR Macedonia } \\
\hline (J) & $\begin{array}{l}\text { Ilinden - Saint } \\
\text { Ilija's Day }\end{array}$ & NDR & Kruševo & $\begin{array}{l}\text { Uprising against } \\
\text { the Turks in } 1903\end{array}$ & c. 5,000 \\
\hline
\end{tabular}


Figure 2 - Dark Events in the Former Yugoslavia categorised using collective memory

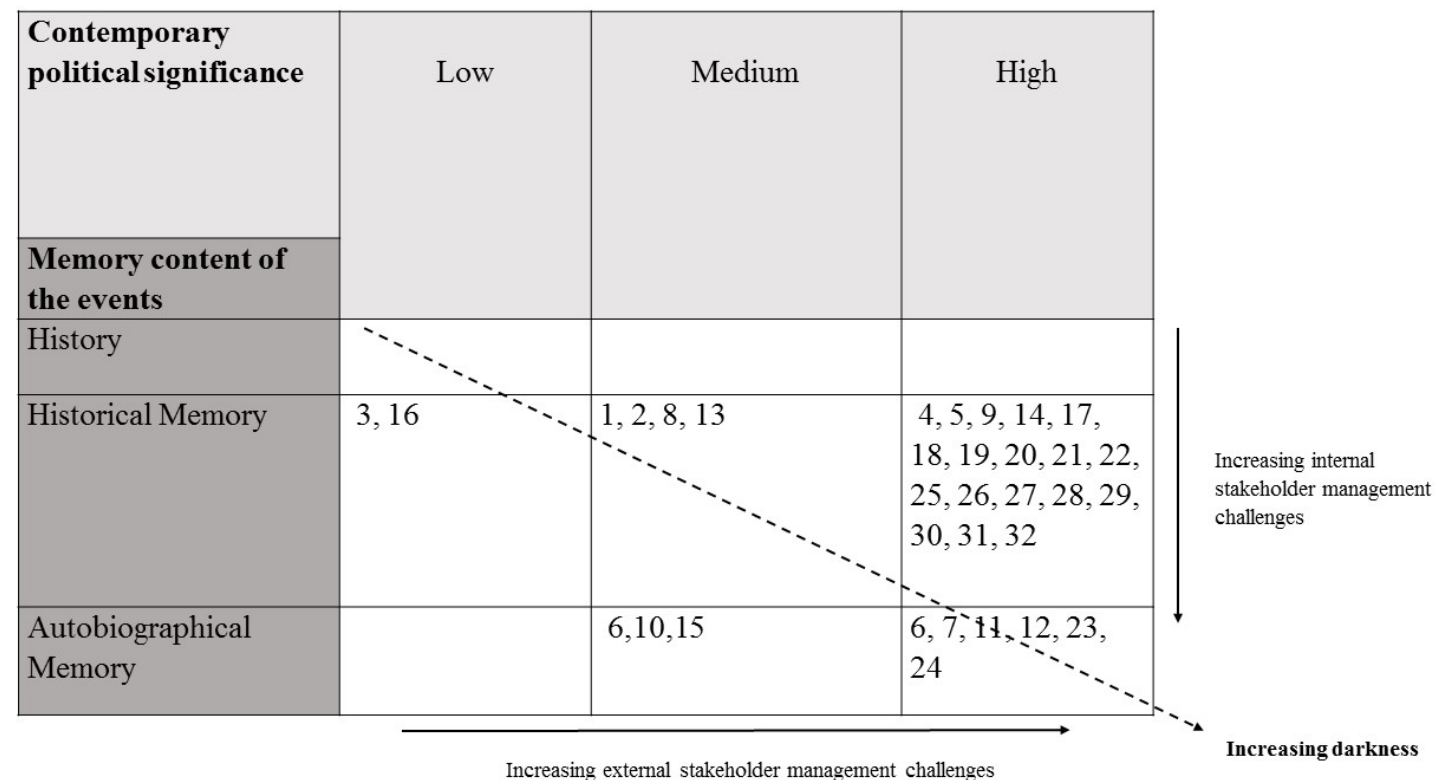

' After Frost and Laing (2013): DE - Dark exhibitions, DRE - Dark re-enactments, NDR National days of mourning or remembrance, MSP - Memorial services, opening of memorials, concerts, performances, SA- Significant anniversaries (e.g. centenaries), PMP Parades, marches, processions, FE - Festivals.

ii After Frost and Laing (2013): DE - Dark exhibitions, DRE - Dark re-enactments, NDR National days of mourning or remembrance, MSP - Memorial services, opening of memorials, concerts, performances, SA- Significant anniversaries (e.g. centenaries), PMP Parades, marches, processions, FE - Festivals. 